\title{
Proteomic Analysis of Grain Protein in the Winter Wheat Jimai44 and Jimai229 Based on Strong Gluten Characteristics
}

\section{FengXin Mao}

Crop Research Institute区Shandong Academy of Agricultural of Agricultural Sciences/Key Laboratory of Wheat Biology \& Genetic Improvement on North Yellow \& Huai River Valley, Ministry of Agriculture/National Engineering Laboratory for Wheat \& Maize『Jinan 250100『China

\section{Ran Han}

Crop Research Institute『Shandong Academy of Agricultural of Agricultural Sciences/Key Laboratory of Wheat Biology \& Genetic Improvement on North Yellow \& Huai River Valley, Ministry of Agriculture/National Engineering Laboratory for Wheat \& Maize区Jinan 250100『China

\section{Ran Han}

Crop Research Institute『Shandong Academy of Agricultural of Agricultural Sciences/Key Laboratory of Wheat Biology \& Genetic Improvement on North Yellow \& Huai River Valley, Ministry of Agriculture/National Engineering Laboratory for Wheat \& Maize区Jinan 250100冈China

\section{Dungong Cheng}

Crop Research Institute『Shandong Academy of Agricultural of Agricultural Sciences/Key Laboratory of Wheat Biology \& Genetic Improvement on North Yellow \& Huai River Valley, Ministry of Agriculture/National Engineering Laboratory for Wheat \& Maize区Jinan 250100هChina

\section{Dungong Cheng}

Crop Research Institute区Shandong Academy of Agricultural of Agricultural Sciences/Key Laboratory of Wheat Biology \& Genetic Improvement on North Yellow \& Huai River Valley, Ministry of Agriculture/National Engineering Laboratory for Wheat \& Maize区Jinan 250100खChina

\section{Haosheng Li}

Crop Research Institute区Shandong Academy of Agricultural of Agricultural Sciences/Key Laboratory of Wheat Biology \& Genetic Improvement on North Yellow \& Huai River Valley, Ministry of Agriculture/National Engineering Laboratory for Wheat \& Maize区Jinan 250100खChina

\section{Haosheng Li}

Crop Research Institute『Shandong Academy of Agricultural of Agricultural Sciences/Key Laboratory of Wheat Biology \& Genetic Improvement on North Yellow \& Huai River Valley, Ministry of Agriculture/National Engineering Laboratory for Wheat \& Maize区Jinan 250100『China

\section{Jianjun Liu}

Crop Research Institute®Shandong Academy of Agricultural of Agricultural Sciences/Key Laboratory of Wheat Biology \& Genetic Improvement on North Yellow \& Huai River Valley, Ministry of Agriculture/National Engineering Laboratory for Wheat \& Maize区Jinan 250100『China 
Crop Research Institute『Shandong Academy of Agricultural of Agricultural Sciences/Key Laboratory of Wheat Biology \& Genetic Improvement on North Yellow \& Huai River Valley, Ministry of Agriculture/National Engineering Laboratory for Wheat \& Maize『Jinan 250100®China

\section{Xinyou Cao}

Crop Research Institute区Shandong Academy of Agricultural of Agricultural Sciences/Key Laboratory of Wheat Biology \& Genetic Improvement on North Yellow \& Huai River Valley, Ministry of Agriculture/National Engineering Laboratory for Wheat \& Maize区Jinan 250100هChina

\section{Xinyou Cao}

Crop Research Institute区Shandong Academy of Agricultural of Agricultural Sciences/Key Laboratory of Wheat Biology \& Genetic Improvement on North Yellow \& Huai River Valley, Ministry of Agriculture/National Engineering Laboratory for Wheat \& Maize区Jinan 250100هChina

\section{Jianmin Song}

Crop Research Institute区Shandong Academy of Agricultural of Agricultural Sciences/Key Laboratory of Wheat Biology \& Genetic Improvement on North Yellow \& Huai River Valley, Ministry of Agriculture/National Engineering Laboratory for Wheat \& Maize囚Jinan 250100هChina

\section{Jianmin Song}

Crop Research Institute区Shandong Academy of Agricultural of Agricultural Sciences/Key Laboratory of Wheat Biology \& Genetic Improvement on North Yellow \& Huai River Valley, Ministry of Agriculture/National Engineering Laboratory for Wheat \& Maize区Jinan 250100هChina

\section{Cheng Liu}

Crop Research Institute邓Shandong Academy of Agricultural of Agricultural Sciences/Key Laboratory of Wheat Biology \& Genetic Improvement on North Yellow \& Huai River Valley, Ministry of Agriculture/National Engineering Laboratory for Wheat \& Maize区Jinan 250100هChina

\section{Cheng Liu}

Crop Research Institute区Shandong Academy of Agricultural of Agricultural Sciences/Key Laboratory of Wheat Biology \& Genetic Improvement on North Yellow \& Huai River Valley, Ministry of Agriculture/National Engineering Laboratory for Wheat \& Maize区Jinan 250100खChina

\section{Jun Guo}

Crop Research Institute『Shandong Academy of Agricultural of Agricultural Sciences/Key Laboratory of Wheat Biology \& Genetic Improvement on North Yellow \& Huai River Valley, Ministry of Agriculture/National Engineering Laboratory for Wheat \& Maize区Jinan 250100खChina

\section{Jun Guo}

Crop Research Institute『Shandong Academy of Agricultural of Agricultural Sciences/Key Laboratory of Wheat Biology \& Genetic Improvement on North Yellow \& Huai River Valley, Ministry of Agriculture/National Engineering Laboratory for Wheat \& Maize区Jinan 250100هChina

\section{Faji Li}

Crop Research Institute『Shandong Academy of Agricultural of Agricultural Sciences/Key Laboratory of Wheat Biology \& Genetic Improvement on North Yellow \& Huai River Valley, Ministry of Agriculture/National Engineering Laboratory for Wheat \& Maize区Jinan 250100هChina

\section{Faji Li}


Crop Research Institute『Shandong Academy of Agricultural of Agricultural Sciences/Key Laboratory of Wheat Biology \& Genetic Improvement on North Yellow \& Huai River Valley, Ministry of Agriculture/National Engineering Laboratory for Wheat \& Maize『Jinan 250100『China

\section{Shengnan Zhai}

Crop Research Institute区Shandong Academy of Agricultural of Agricultural Sciences/Key Laboratory of Wheat Biology \& Genetic Improvement on North Yellow \& Huai River Valley, Ministry of Agriculture/National Engineering Laboratory for Wheat \& Maize区Jinan 250100هChina

\section{Shengnan Zhai}

Crop Research Institute区Shandong Academy of Agricultural of Agricultural Sciences/Key Laboratory of Wheat Biology \& Genetic Improvement on North Yellow \& Huai River Valley, Ministry of Agriculture/National Engineering Laboratory for Wheat \& Maize区Jinan 250100هChina

\section{Yan Zi}

Crop Research Institute区Shandong Academy of Agricultural of Agricultural Sciences/Key Laboratory of Wheat Biology \& Genetic Improvement on North Yellow \& Huai River Valley, Ministry of Agriculture/National Engineering Laboratory for Wheat \& Maize囚Jinan 250100هChina

\section{Yan Zi}

Crop Research Institute区Shandong Academy of Agricultural of Agricultural Sciences/Key Laboratory of Wheat Biology \& Genetic Improvement on North Yellow \& Huai River Valley, Ministry of Agriculture/National Engineering Laboratory for Wheat \& Maize区Jinan 250100هChina

\section{Xiaolu Wang}

Crop Research Institute『Shandong Academy of Agricultural of Agricultural Sciences/Key Laboratory of Wheat Biology \& Genetic Improvement on North Yellow \& Huai River Valley, Ministry of Agriculture/National Engineering Laboratory for Wheat \& Maize区Jinan 250100هChina

\section{Xiaolu Wang}

Crop Research Institute区Shandong Academy of Agricultural of Agricultural Sciences/Key Laboratory of Wheat Biology \& Genetic Improvement on North Yellow \& Huai River Valley, Ministry of Agriculture/National Engineering Laboratory for Wheat \& Maize区Jinan 250100खChina

\section{Zhendong Zhao}

Crop Research Institute『Shandong Academy of Agricultural of Agricultural Sciences/Key Laboratory of Wheat Biology \& Genetic Improvement on North Yellow \& Huai River Valley, Ministry of Agriculture/National Engineering Laboratory for Wheat \& Maize囚Jinan 250100هChina

\section{Zhendong Zhao}

Crop Research Institute『Shandong Academy of Agricultural of Agricultural Sciences/Key Laboratory of Wheat Biology \& Genetic Improvement on North Yellow \& Huai River Valley, Ministry of Agriculture/National Engineering Laboratory for Wheat \& Maize『Jinan 250100『China

\section{Aifeng Liu (D2020201055@stu.njau.edu.cn )}

Crop Research Institute『Shandong Academy of Agricultural of Agricultural Sciences/Key Laboratory of Wheat Biology \& Genetic Improvement on North Yellow \& Huai River Valley, Ministry of Agriculture/National Engineering Laboratory for Wheat \& Maize『Jinan 250100囚China 
Research

Keywords: Wheat, Strong gluten, Quality, Proteome

Posted Date: October 19th, 2020

DOI: https://doi.org/10.21203/rs.3.rs-93097/v1

License: (c) (1) This work is licensed under a Creative Commons Attribution 4.0 International License. Read Full License 


\section{Abstract}

Background囚To determine the grain proteome of the strong gluten wheat, TMT technology was used to analyze proteomic differences between the winter wheat varieties Jimai 44 and the strong gluten Jimai 229.

Results $\llbracket$ Comparisons were also made with the winter wheat Jimai 22 as a control. It was found that there were 120 differentially expressed proteins between Jimai 44 and Jimai 22, while 173 between Jimai 229 and Jimai 22. Among these, 27 proteins were up-regulated and 23 down-regulated in jimai 44 and in jimai 229.

Conclusions $₫ G O$ analysis and KEGG pathway analysis showed that the differentially expressed proteins were mainly enriched in cell functions relating to nutrient reservoir activity, metabolic processes, protein processing in endoplasmic reticulum, phenylpropane biosynthesis and nitrogen metabolism. Amongst the screened proteins, many differences were related to storage proteins. This study provides an important basis for further exploring the key factors of quality improvement and genetic variation of gluten protein expression.

\section{Background}

Wheat is an important nutrient source for humans and about one third of the world's population use it as their main form of food intake. Therefore, understanding its protein content and quality is extremely important ${ }^{[1]}$. Wheat quality is the key indicator and main purpose of wheat quality breeding ${ }^{[2]}$. Wheat quality mainly refers to the end-use quality of flour ${ }^{[3-5]}$. The content of gluten protein affects the physical and chemical characteristics of wheat flour and the quality of food processing to bake bread and steamed bread. Although the gene expression of gluten protein is mainly regulated at the transcriptional level, proteomic information plays an important role in studying the effect of different gluten protein types on dough characteristics and the accumulation level of different gluten proteins in wheat ${ }^{[6-7]}$.

Developing proteomic approaches provides the possibility to study the dynamic changes of gluten protein components and characteristics closely related to the processing performance of wheat flour. Furthermore, it also provides a theoretical basis for improving the breeding processes and quality of wheat varieties. Proteomics research can be used to separate gluten proteins by two-dimensional gel electrophoresis (2-DE) or liquid chromatography for mass spectrometry analysis ${ }^{[8-12]}$. Dupont et al. ${ }^{[13]}$ detected the expression of 5 variants of HMW-GS, 22 variants of LMW-GS, 23 variants of a - gliadin, 13 variants of $\gamma$ - gliadin and 7 variants of $\omega$ - gliadin in flour. Although Cho et al. ${ }^{[14]} \mathrm{did}$ not associate glutenin with its coding gene, 23 variants of a-gliadin, 11 variants of $\gamma$-gliadin and 5 variants of $\omega$-gliadin were identified in Keumkang varieties in Korea. Dong ${ }^{[15]}$ detected 11 variants of LMW-GS in grains of Xiaoyan 54, which supports the transcriptomic and proteomic data. Other studies found that environmental factors or tillage practices may cause a small part of gluten expression. Drought or salt stress tend to increase the accumulation of $a$ - and $\omega$ - gliadin and HMW-GS, while the expression of a - gliadin seems to be more affected by heat and drought, indicating that this type of gliadin protein regulation is more sensitive to abiotic stress ${ }^{[16-19]}$.

To date, the genomic analysis of wheat gluten has been extensively studied. Identifying the proteome of wheat gluten will provide new directions for wheat quality-related functional genomics. This study intends to analyze the proteomics of the strong gluten wheat varieties Jimai 44 and Jimai 229 to further explore the key 
factors related to wheat quality improvement. By effectively utilizing the genetic variations of gluten protein structures and expressions in wheat grains, this data could provide important selection criteria for the cultivation and quality improvement of the strong gluten wheat varieties.

\section{Results And Discussion}

\section{Identification and quantification of differentially expressed proteins in wheat grain}

The results of TMT proteomics analysis were obtained by matching with the wheat protein database. 6,627 proteins were identified in the sample grains of which 5,428 proteins were quantifiable. Next, based on the protein abundance level and a difference of at least 1.5 folds, these proteins were screened and analyzed. This approach revealed that 120 were differentially expressed between Jimai 44 and Jimai 22. This included 63 up-regulated proteins, 57 down-regulated proteins and 173 differentially expressed proteins between Jimai 229 and Jimai 22. Among them, 86 proteins were up-regulated and 87 were down-regulated. Amongst the differentially expressed proteins between Jimai 229 and Jimai 44, 27 proteins were the same up-regulated proteins and 23 were the same down-regulated proteins (Figure 1). In addition, there were differences in the number of differentially expressed proteins between Jimai 44 and Jimai 229. Jimai 44 had 20 specific proteins (including 9 up-regulated and 11 down-regulated proteins), and Jimai 229 had 73 specific proteins (including 32 up-regulated and 11 down-regulated proteins). These results show that the protein content of the strong gluten wheat is different from ordinary wheat and the protein content of the strong gluten wheat Jimai 44 and Jimai 229 are also distinct.

\section{GO analysis of differentially expressed proteins}

According to the uniport (Swiss prot / TrEMBL) and gene ontology databases, the subcellular localization and go functional classification of the detected differential proteins between Jimai 44 and Jimai 22, and Jimai 229 and Jimai 22 were analyzed using wolfpsort (Table 1). These results show key differences in the protein contents between the strong gluten wheat Jimai 44 and Jimai 229, and the common wheat Jimai 22 where the main differences were detected in the chloroplast, extracellular, cytoplasm and nucleus.

Differentially expressed proteins (DEPs) were annotated by GO (gene ontology) and classified into three categories: biological processes, molecular functions and cell compositions. The different proteins in the grains of the strong gluten wheat Jimai 44, Jimai 229 and the common wheat Jimai 22 involved multiple biological processes and molecular functions (Table 1). There were 7 kinds of differential proteins in Jimai 44 and Jimai 22. There were 35 differential proteins in metabolic process types, accounting for $31 \%$ of the total differential proteins. There were also many differential proteins in cell processes and single-cell biological process type, accounting for $21 \%$ and $16 \%$ of the total differential proteins respectively. Among them, metabolic processes (35) and cell processes (23) are the most important biological processes. Amongst the biological process categories of differentially expressed proteins in Jimai 229 and Jimai 22, the metabolic process (50) and cell process (41) were also the most important biological processes, and the number of differential proteins accounted for more than that of Jimai 44.The molecular function categories of the differential proteins of Jimai 44 and Jimai 22 mainly included catalytic activity (37), binding (25), nutrient storage activity (20), molecular function regulation (9), antioxidant activity (6), transport activity (2) and other 
activities of which the catalytic activity and binding occupy the two largest functional categories. There were mainly 5 types of molecular functional categories of the differentially expressed protein molecules of Jimai 229 and Jinmai 22, catalytic activity (60), binding (57), nutrient storage activity (24), molecular function regulation (14) and antioxidant activity (6), of which catalytic activity (60) and binding (57) are the two largest functional categories. There are no differential proteins related to transport activity in Jimai 229 and Jimai 22. In the cell composition category of Jimai 44 and Jimai 22, the differential proteins were primarily located in the intercellular region (11) and the cell membrane (8). In the cell composition category of Jimai 229 and Jimai 22, the differential proteins were mainly located in cells (20) and extracellular regions (12).

GO analysis showed that the strong gluten wheat Jimai 44 and Jimai 229 compared with the common wheat grain Jimai 22. Differences were mainly involved in nutrient storage activities, metabolic processes and other biological processes related to quality formation and metabolism.

According to the $\mathrm{GO}$ functional enrichment analysis, the differentially expressed proteins in the strong gluten wheats Jimai 44, Jimai 229 and the common wheat Jimai 22 were significantly enriched in molecular functions and biological processes (table2). These were mainly related to biological activities such as nutrient reservoir activity, negative regulation of protein metabolic processes and negative regulation of cell metabolic processes. The up-regulated proteins in Jimai 229 and Jimai 22 were significantly accumulated in cell components, molecular functions and biological processes, and were mainly involved in the negative regulation of nutrient reservoir activity, enzyme inhibitor activity and regulation of protein metabolic processes. The strong gluten wheats Jimai 44, Jimai 229 and the common wheat Jimai 22 were differentially expressed and the down-regulated proteins were enriched in GO function (Table 3). The enrichment level of differentially expressed down-regulated proteins of Jimai 44 and Jimai 22 were relatively low $(<3.0)$, of which the enrichment level of down-regulated proteins related to nutrient reservoir activity was relatively high (8.52). The enrichment level of down regulated proteins in Jimai 229 and Jimai 22 were also relatively low $(<3.0)$, however were enriched in the nutrient reservoir activity (30.34).

According to the GO functional enrichment analysis, the differentially expressed proteins between the strong gluten wheat Jimai 44 and Jimai 229 were most abundant in nutrient reservoir activity when compared with the common wheat Jimai 22, which was related to quality formation and was also the main difference between the strong gluten wheat and the common wheat. 
Table 1 Prediction of the sub-cellular locations of the differentially expressed proteins based on bioinformatics analysis of the mentioned differentially abundant poteins through Gene Ontology(GO)in three domains of jimai44[jimai229 and jimai22

\begin{tabular}{|c|c|c|c|c|}
\hline & & & Jimai44/Jimai22 & Jimai229/Jimai22 \\
\hline & & & No. of Protein & No. of Protein \\
\hline $\begin{array}{l}\text { GO } \\
\text { Analysis }\end{array}$ & $\begin{array}{l}\text { Biological } \\
\text { Process }\end{array}$ & metabolic process & 35 & 50 \\
\hline & & cellular process & 23 & 41 \\
\hline & & single-organism process & 18 & 34 \\
\hline & & response to stimulus & 16 & 18 \\
\hline & & biological regulation & 12 & 19 \\
\hline & & localization & 4 & 5 \\
\hline & & other & 3 & 1 \\
\hline & $\begin{array}{l}\text { Cellular } \\
\text { Component }\end{array}$ & extracellular region & 11 & 12 \\
\hline & & membrane & 8 & 6 \\
\hline & & cell & 3 & 20 \\
\hline & & organelle & 2 & 11 \\
\hline & & $\begin{array}{l}\text { macromolecular } \\
\text { complex }\end{array}$ & 2 & 7 \\
\hline & & other & 0 & 1 \\
\hline & $\begin{array}{l}\text { Molecular } \\
\text { Function }\end{array}$ & catalytic activity & 37 & 60 \\
\hline & & binding & 25 & 57 \\
\hline & & $\begin{array}{l}\text { nutrient reservoir } \\
\text { activity }\end{array}$ & 20 & 24 \\
\hline & & $\begin{array}{l}\text { molecular function } \\
\text { regulator }\end{array}$ & 9 & 14 \\
\hline & & antioxidant activity & 6 & 6 \\
\hline & & transporter activity & 2 & 0 \\
\hline & & other & 1 & 5 \\
\hline Subcellula & ocalization & chloroplast & 51 & 58 \\
\hline & & extracellular & 24 & 32 \\
\hline & & cytoplasm & 18 & 41 \\
\hline
\end{tabular}




\begin{tabular}{|lll|}
\hline vacuolar membrane & 9 & 14 \\
\hline nucleus & 9 & 17 \\
\hline plasma membrane & 4 & 0 \\
\hline mitochondria & 0 & 6 \\
\hline other & 5 & 5 \\
\hline
\end{tabular}


Table 2 Differentially up-regulated proteins of Jimai 44, Jimai 229 and Jimai 22 in GO enrichment analysis

\begin{tabular}{|c|c|c|c|c|c|c|}
\hline & $\begin{array}{l}\text { GO Terms } \\
\text { Level } 1\end{array}$ & $\begin{array}{l}\text { GO Terms } \\
\text { Description }\end{array}$ & Mapping & Background & $\begin{array}{l}\text { Fold } \\
\text { Enrichment }\end{array}$ & $\begin{array}{l}- \\
\text { log10(p } \\
\text { value) }\end{array}$ \\
\hline \multirow[t]{13}{*}{ Jimai44/Jimai 22} & $\begin{array}{l}\text { Cellular } \\
\text { Component }\end{array}$ & $\begin{array}{l}\text { extracellular } \\
\text { region }\end{array}$ & 6 & 124 & 6.98 & 3.25 \\
\hline & $\begin{array}{l}\text { Molecular } \\
\text { Function }\end{array}$ & $\begin{array}{l}\text { nutrient } \\
\text { reservoir } \\
\text { activity }\end{array}$ & 10 & 89 & 12.54 & 7.34 \\
\hline & & $\begin{array}{l}\text { serine-type } \\
\text { endopeptidase } \\
\text { inhibitor } \\
\text { activity }\end{array}$ & 6 & 69 & 9.71 & 3.53 \\
\hline & & $\begin{array}{l}\text { peptidase } \\
\text { regulator } \\
\text { activity }\end{array}$ & 6 & 88 & 7.61 & 3.04 \\
\hline & & $\begin{array}{l}\text { Endopeptidase } \\
\text { inhibitor } \\
\text { activity }\end{array}$ & 6 & 88 & 7.61 & 3.04 \\
\hline & & $\begin{array}{l}\text { peptidase } \\
\text { inhibitor } \\
\text { activity }\end{array}$ & 6 & 88 & 7.61 & 3.04 \\
\hline & & $\begin{array}{l}\text { endopeptidase } \\
\text { regulator } \\
\text { activity }\end{array}$ & 6 & 88 & 7.61 & 3.04 \\
\hline & & $\begin{array}{l}\text { enzyme } \\
\text { inhibitor } \\
\text { activity }\end{array}$ & 6 & 109 & 6.14 & 2.62 \\
\hline & & $\begin{array}{l}\text { enzyme } \\
\text { regulator } \\
\text { activity }\end{array}$ & 6 & 142 & 4.72 & 2.13 \\
\hline & $\begin{array}{l}\text { Biological } \\
\text { Process }\end{array}$ & $\begin{array}{l}\text { negative } \\
\text { regulation of } \\
\text { protein } \\
\text { metabolic } \\
\text { process }\end{array}$ & 7 & 72 & 11 & 4.6 \\
\hline & & $\begin{array}{l}\text { negative } \\
\text { regulation of } \\
\text { cellular } \\
\text { metabolic } \\
\text { process }\end{array}$ & 7 & 74 & 10.71 & 4.54 \\
\hline & & $\begin{array}{l}\text { regulation of } \\
\text { cellular protein } \\
\text { metabolic } \\
\text { process }\end{array}$ & 7 & 100 & 7.92 & 3.8 \\
\hline & & regulation of & 6 & 65 & 10.45 & 3.72 \\
\hline
\end{tabular}




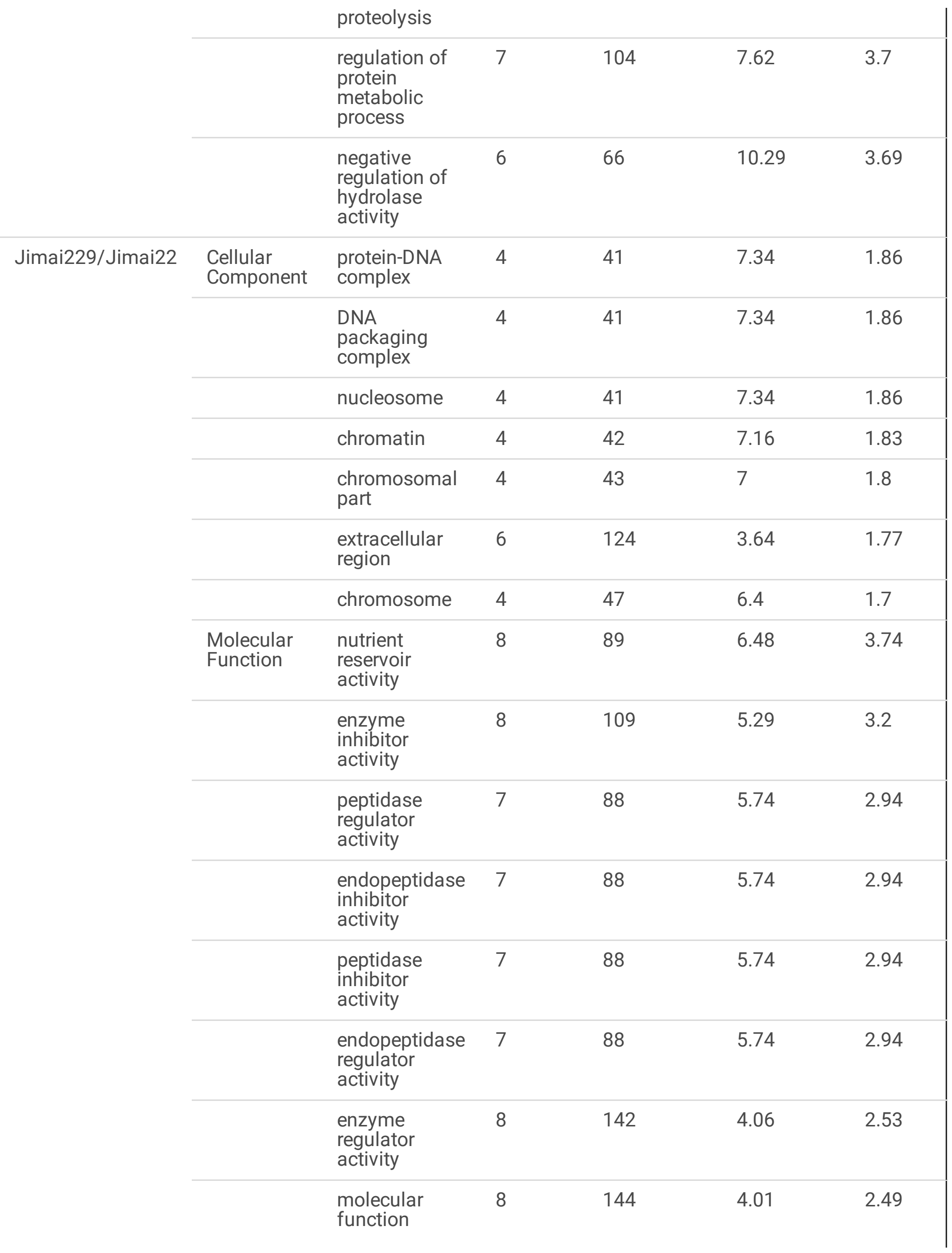




\begin{tabular}{|c|c|c|c|c|c|}
\hline \multirow[t]{6}{*}{$\begin{array}{l}\text { Biological } \\
\text { Process }\end{array}$} & $\begin{array}{l}\text { negative } \\
\text { regulation of } \\
\text { protein } \\
\text { metabolic } \\
\text { process }\end{array}$ & 6 & 72 & 6.71 & 2.79 \\
\hline & $\begin{array}{l}\text { negative } \\
\text { regulation of } \\
\text { cellular } \\
\text { metabolic } \\
\text { process }\end{array}$ & 6 & 74 & 6.53 & 2.74 \\
\hline & $\begin{array}{l}\text { regulation of } \\
\text { cellular protein } \\
\text { metabolic } \\
\text { process }\end{array}$ & 6 & 100 & 4.83 & 2.17 \\
\hline & $\begin{array}{l}\text { regulation of } \\
\text { proteolysis }\end{array}$ & 5 & 65 & 6.19 & 2.13 \\
\hline & $\begin{array}{l}\text { negative } \\
\text { regulation of } \\
\text { hydrolase } \\
\text { activity }\end{array}$ & 5 & 66 & 6.1 & 2.1 \\
\hline & $\begin{array}{l}\text { regulation of } \\
\text { protein } \\
\text { metabolic } \\
\text { process }\end{array}$ & 6 & 104 & 4.64 & 2.1 \\
\hline
\end{tabular}


Table 3 Differentially down-regulated proteins of Jimai 44, Jimai 229 and Jimai 22 in GO enrichment analysis

\begin{tabular}{|c|c|c|c|c|c|c|}
\hline & $\begin{array}{l}\text { GO Terms } \\
\text { Level } 1\end{array}$ & $\begin{array}{l}\text { GO Terms } \\
\text { Description }\end{array}$ & Mapping & Background & $\begin{array}{l}\text { Fold } \\
\text { Enrichment }\end{array}$ & $\begin{array}{l}- \\
\log 10(p \\
\text { value })\end{array}$ \\
\hline \multirow[t]{6}{*}{ Jimai44/Jimai22 } & $\begin{array}{l}\text { Cellular } \\
\text { Component }\end{array}$ & $\begin{array}{l}\text { extracellular } \\
\text { region }\end{array}$ & 5 & 124 & 7.75 & 2.85 \\
\hline & $\begin{array}{l}\text { Molecular } \\
\text { Function }\end{array}$ & $\begin{array}{l}\text { nutrient } \\
\text { reservoir } \\
\text { activity }\end{array}$ & 10 & 89 & 16.46 & 8.52 \\
\hline & & $\begin{array}{l}\text { antioxidant } \\
\text { activity }\end{array}$ & 4 & 87 & 6.74 & 1.72 \\
\hline & $\begin{array}{l}\text { Biological } \\
\text { Process }\end{array}$ & $\begin{array}{l}\text { cellular } \\
\text { oxidant } \\
\text { detoxification }\end{array}$ & 4 & 65 & 9.29 & 2.12 \\
\hline & & $\begin{array}{l}\text { cellular } \\
\text { detoxification }\end{array}$ & 4 & 65 & 9.29 & 2.12 \\
\hline & & $\begin{array}{l}\text { hydrogen } \\
\text { peroxide } \\
\text { catabolic } \\
\text { process }\end{array}$ & 3 & 47 & 9.63 & 1.46 \\
\hline \multirow[t]{8}{*}{ Jimai229/Jiami22 } & $\begin{array}{l}\text { Cellular } \\
\text { Component }\end{array}$ & $\begin{array}{l}\text { extracellular } \\
\text { region }\end{array}$ & 6 & 124 & 5.98 & 2.85 \\
\hline & $\begin{array}{l}\text { Molecular } \\
\text { Function }\end{array}$ & $\begin{array}{l}\text { nutrient } \\
\text { reservoir } \\
\text { activity }\end{array}$ & 16 & 89 & 14.53 & 30.34 \\
\hline & & $\begin{array}{l}\text { serine-type } \\
\text { endopeptidase } \\
\text { inhibitor } \\
\text { activity }\end{array}$ & 5 & 69 & 5.86 & 2.02 \\
\hline & & $\begin{array}{l}\text { peptidase } \\
\text { regulator } \\
\text { activity }\end{array}$ & 5 & 88 & 4.59 & 1.67 \\
\hline & & $\begin{array}{l}\text { peptidase } \\
\text { inhibitor } \\
\text { activity }\end{array}$ & 5 & 88 & 4.59 & 1.67 \\
\hline & & $\begin{array}{l}\text { endopeptidase } \\
\text { regulator } \\
\text { activity }\end{array}$ & 5 & 88 & 4.59 & 1.67 \\
\hline & & $\begin{array}{l}\text { endopeptidase } \\
\text { inhibitor } \\
\text { activity }\end{array}$ & 5 & 88 & 4.59 & 1.67 \\
\hline & & $\begin{array}{l}\text { enzyme } \\
\text { regulator } \\
\text { activity }\end{array}$ & 6 & 142 & 3.42 & 1.55 \\
\hline
\end{tabular}




\begin{tabular}{llcccc|} 
& $\begin{array}{l}\text { molecular } \\
\text { function } \\
\text { regulator }\end{array}$ & 6 & 144 & 3.37 & 1.53 \\
\hline $\begin{array}{l}\text { Biological } \\
\text { Process }\end{array}$ & $\begin{array}{l}\text { cellular } \\
\text { oxidant } \\
\text { detoxification }\end{array}$ & 4 & 65 & 6.19 & 1.62 \\
\hline & $\begin{array}{l}\text { cellular } \\
\text { detoxification }\end{array}$ & 4 & 65 & 6.19 & 1.62 \\
\hline
\end{tabular}

\section{KEGG analysis of differentially expressed proteins}

KEGG(Kyoto Encylopedia of Genes and Genomes) is a network information database that provides signal transmission, biochemical reactions, and metabolism to connect known molecular interactions, such as metabolic pathways, complexes, and biochemical reactions. KEGG analysis revealed a significant change in one differential proteins of Jimai 44 and Jimai 22 (Figure 2). Furthermore, the most abundant differential proteins were enriched in "endoplasmic reticulum protein processing". Four pathways of differential proteins between Jimai 229 and Jimai 22 showed significant changes (Figure 3). "Nitrogen metabolism", "Biosynthesis of secondary metabolites", "Amino acid biosynthesis" and "Phenylpropane biosynthesis" were the 4 pathways with the most differential proteins. In the nitrogen metabolism pathway, there were six differentially expressed proteins (P18573, P04726, J7HT09, X2KVH9, Q6RUI9, A0A0K2QJX7), of which P18573 (3.584), P04726 (4.209) and two others were differentially up-regulated in Jimai 229 by 3.5 folds. J7HT09 (1.617), X2KVH9 (3.448), A0A0K2QJX7 (6.284) and three other differentially expressed proteins were up-regulated by more than 3 folds in Jimai 44. All five proteins were related to $\alpha / \beta$ - gliadin, and their expression levels in the strong gluten wheat were higher than that in Jimai 22. In the endoplasmic reticulum protein processing pathway, the number of heat shock related proteins in Jimai 44 were higher than that in Jimai 229.

\section{Hierarchical cluster analysis of go enrichment, KEGG pathway enrichment and protein domain enrichment}

To determine the correlation between the functions of differential proteins in the strong gluten wheats Jimai 44 and Jimai 229, hierarchical cluster analysis was conducted on GO enrichment, KEGG pathway enrichment and protein domain enrichment. According to these analysis, the differentially expressed proteins were divided into four quantitative categories: Q1 $(0<$ Q1 < 0.667), Q2 $(0.667<$ Q2 < 0.769$)$, Q3 $(1.3<$ Q3 < 1.5) and Q4 (Q4 > 1.5).

The results of hierarchical clustering analysis based on GO function are shown in Fig. 4 and Fig. 5. In the molecular function category, the up-regulated proteins in the differential proteins (Fig. 4-A) of the strong gluten wheat Jimai 44 and Jimai 22 were mainly related to nutrient reservoir activity, 6-phosphate fructokinase activity and phosphofructose fructokinase activity, which were related to quality protein formation and energy metabolism. The down-regulated proteins were mainly related to nutrient reservoir activity. The differential proteins between the strong gluten wheat Jimai 229 and Jimai 22 were mainly related to nutrient reservoir activity (Fig. 5-A). The up-regulated proteins were mainly related to the nutrient reservoir activity, protein heterodimerization activity, protein dimer activity, structural molecular activity and 
other molecular functions, while the down-regulated proteins were mainly related to the nutrient reservoir activity. In the category of biological processes, the up-regulated differential proteins in Jimai 44 and Jimai 22 (Fig. 4-B) have a strong correlation with biological processes such as the negative regulation of protein metabolic processes, regulation of cellular metabolic processes, nucleoside phosphate metabolic processes and ribose phosphate metabolic processes. In comparison, most of the down-regulated differential proteins are related to biological processes such as cellular oxidant detoxification and cellular detoxification. Amongst the differentially expressed proteins of the strong gluten wheat Jimai 229 and Jimai 22 (Fig. 5-B), the upregulated differential proteins were related to the regulation of protein metabolic processes, proteolysis and the negative regulation of protein metabolic processes. while most of the down-regulated differential proteins were related to cell defense. The analysis of cell composition categories showed that the differential proteins of Jimai 44 were related to extracellular regions (Fig. 4-C) and the differential proteins of Jimai 229 were mainly related to the chromosomes, nucleosome regions and cell regions (Fig. 5-C).

The results of layer clustering analysis based on KEGG are shown in Figure 6-A and Figure 7-A. The differential proteins of the strong gluten wheat Jimai 44 and Jimai 22 are mainly related to four pathways. Carbon fixation in photosynthetic organisms, Glycolysis/Gluconeogenesis, pentose phosphate, and fructose and mannose metabolism are the main pathways of the differential proteins. Protein processing and nitrogen metabolism pathway in endoplasmic reticulum are the main pathways in the differential proteins of Jimai 229 and Jimai 22.

Hierarchical clustering analysis based on protein domains is shown in Figure 6-B and Figure 7-B. In the differentially expressed proteins of the strong gluten wheat Jimai 44 and Jimai 22 (Figure 6-B), the upregulated protein were related to Pyrophosphate-dependent phosphofructokinase, alpha-helical domain, serine protease inhibitor domain and phosphofructokinase domain, while the down-regulated differential protein were related to secretory peroxidase. The differentially expressed protein of the strong gluten wheat Jimai 229 and Jimai 22(Figure 7-B), the up-regulated protein is related to histone $\mathrm{H} 2 \mathrm{~A} / \mathrm{H} 2 \mathrm{~B} / \mathrm{H} 3$, histone folding, calreticulin/calnexin, $\mathrm{P}$ domain and other protein domains, and the down-regulated differential protein were related to Bifunctional trypsin/alpha-amylase inhibitor helical domain and bifunctional inhibitor/plant lipid transfer protein/seed storage helix domain.

Hierarchical cluster analysis showed that the differentially expressed proteins of the strong gluten wheat Jimai 44 and Jimai 229 were more involved in the process of nutrient reservoir activity and protein regulation compared with the common wheat Jimai 22 , which was related to the formation of quality related traits and the regulation of storage protein synthesis.

\section{Conclusion}

In this study, the proteomics of the mature grains of the high-quality strong gluten wheat Jimai 44 and Jimai 229 were analyzed and many different proteins related to storage proteins were detected. We found that HMW-glutenin DY10 (P10387) regulated GLU-D1-2B and has a multiple of 4 difference in Jimai 44 and Jimai 229. Both Jimai 44 and Jimai 229 contain the high-quality polymer protein subunits $5+10$. The high content of the 1DY10 subunit may be one of the reasons for the excellent processing quality of Jimai 44 and Jimai 229. We also found that the HMW-glutenin subunit PW212 (P08489) was up-regulated by 1.8 fold in Jimai 44, 
which may be one of the internal factors influencing the quality of Jimai 44. The low-molecular-weight glutenin subunit is the main component of glutenin and its content is higher than that of the high-molecularweight glutenin subunit. It mainly improves dough strength and ductility. We found that LMW-glutenin ( B2Y2Q1), controlled by GluB3-1, is up-regulated by 2.08 fold in Jimai 229 and down-regulated in Jimai 44. Previous studies have shown that the $b$ and $d$ allelic variation of lu-b3 locus played a more important role in the expression of the doughs physical and chemical properties ${ }^{[22]}$. This subunit expression may be one of the reasons that the bread and noodle scores of Jimai 229 is better. This study found that Alpha-gliadin (A0A0E3Z7G8, A0A0K2QJX7, A0A0E3Z6M6, IOIT52, X2KVH9), controlled by Gli-2, was up-regulated by more than 4 folds in Jimai 44, and the expression level was higher than Jimai 229, which is consistent with the result of high gliadin content in Jimai $44^{[20]}$.

The high-quality strong gluten wheat Jimai 229 and Jimai 44 contain high-quality subunits, and the differential protein expression related to gluten protein is higher than that of the common wheat Jimai 22, resulting in better quality characteristics of Jimai 229 and Jimai 44 compared to Jimai22. At the same time, Jimai 44 and Jimai 229 contain different expression levels of differential proteins, which contributes to some differences in the quality traits of Jimai 44 and Jimai 229. On the basis of these differential proteins, the quality-related traits can be verified by mining the regulated related genes, which provides more accurate theoretical data to support the development of wheat quality and the cultivation of high-quality varieties.

\section{Methods}

The wheat varieties Jimai 44, 229 and 22 were cultivated by the Shandong Academy of Agricultural Sciences and were selected as samples for analysis. Jimai 229 has excellent quality characteristics, determined by $16.71 \%$ grain protein content, $31.1 \%$ wet gluten content, 37.7 min stabilization time, $761.5 \mathrm{BU}$ maximum tensile resistance, $135^{\prime}$ stretch area $181.5 \mathrm{~cm}^{2}, 181.0 \mathrm{~mm}$ extensibility, $1000 \mathrm{ml}$ bread volume and 97 points on the bread score ${ }^{[20]}$. Jimai 44 has excellent quality characteristics, determined by $17.50 \%$, wet gluten content $33.5 \%$, stabilization time $32.8 \mathrm{~min}$, maximum tensile resistance $851.5 \mathrm{BU}, 135^{\prime}$ stretch area $162.7 \mathrm{~cm}^{2}$, extensibility $161.0 \mathrm{~mm}$, bread volume $>1000 \mathrm{ml}$ and 94 points on the bread score ${ }^{[20]}$. The quality characteristics of Jimai 229 and Jimai 44 have the national standard for the strong gluten wheat. Jimai 22 has poor quality characteristics and belongs to the common wheat variety, which is used as a control for the strong gluten varieties. The three test samples were planted in the experimental base situated at the Institute of Crop Research of Shandong Academy of Agricultural Sciences. The mature seeds were selected and stored at $-80^{\circ} \mathrm{C}$ for use at a later period.

\section{Protein Extraction}

The sample was grinded by liquid nitrogen into cell powder and then transferred to a 5-mL centrifuge tube. After that, four volumes of lysis buffer ( $8 \mathrm{M}$ urea, 1\% Triton-100, $10 \mathrm{mM}$ dithiothreitol, and 1\% Protease Inhibitor Cocktail) was added to the cell powder, followed by sonication three times on ice using a high intensity ultrasonic processor (Scientz). The remaining debris was removed by centrifugation at 20,000 $\mathrm{g}$ at 4 ${ }^{\circ} \mathrm{C}$ for $10 \mathrm{~min}$. Finally, the protein was precipitated with cold $20 \%$ TCA for $2 \mathrm{~h}$ at $-20{ }^{\circ} \mathrm{C}$. After centrifugation at $12,000 \mathrm{~g} 4{ }^{\circ} \mathrm{C}$ for $10 \mathrm{~min}$, the supernatant was discarded. The remaining precipitate was washed with cold 
acetone for three times. The protein was redissolved in $8 \mathrm{M}$ urea and the protein concentration was determined with BCA kit according to the manufacturer's instructions.

\section{Trypsin Digestion}

For digestion, the protein solution was reduced with $5 \mathrm{mM}$ dithiothreitol for $30 \mathrm{~min}$ at $56{ }^{\circ} \mathrm{C}$ and alkylated with $11 \mathrm{mM}$ iodoacetamide for $15 \mathrm{~min}$ at room temperature in darkness. The protein sample was then diluted by adding 100 mM TEAB to urea concentration less than 2M. Finally, trypsin was added at 1:50 trypsin-to-protein mass ratio for the first digestion overnight and 1:100 trypsin-to-protein mass ratio for a second $4 \mathrm{~h}$-digestion.

\section{TMT Labeling}

After trypsin digestion, peptide was desalted by Strata X C18 SPE column (Phenomenex) and vacuum-dried. Peptide was reconstituted in 0.5 M TEAB and processed according to the manufacturer's protocol for TMT kit/iTRAQ kit. Briefly, one unit of TMT/iTRAQ reagent were thawed and reconstituted in acetonitrile. The peptide mixtures were then incubated for $2 \mathrm{~h}$ at room temperature and pooled, desalted and dried by vacuum centrifugation.

\section{HPLC Fractionation}

The tryptic peptides were fractionated into fractions by high pH reverse-phase HPLC using Agilent 300Extend C18 column ( $5 \mu \mathrm{m}$ particles, $4.6 \mathrm{~mm}$ ID, $250 \mathrm{~mm}$ length). Briefly, peptides were first separated with a gradient of $8 \%$ to $32 \%$ acetonitrile ( $\mathrm{pH} 9.0$ ) over 60 min into 60 fractions. Then, the peptides were combined into 18 fractions and dried by vacuum centrifuging.

\section{LC-MS/MS Analysis}

The tryptic peptides were dissolved in $0.1 \%$ formic acid (solvent $A$ ), directly loaded onto a home-made reversed-phase analytical column (15-cm length, $75 \mu \mathrm{m}$ i.d.). The gradient was comprised of an increase from $6 \%$ to $23 \%$ solvent B ( $0.1 \%$ formic acid in $98 \%$ acetonitrile) over $26 \mathrm{~min}, 23 \%$ to $35 \%$ in 8 min and climbing to $80 \%$ in 3 min then holding at $80 \%$ for the last $3 \mathrm{~min}$, all at a constant flow rate of $400 \mathrm{~nL} / \mathrm{min}$ on an EASY-nLC 1000 UPLC system.

The peptides were subjected to NSI source followed by tandem mass spectrometry (MS/MS) in Q Exactive EM $^{\mathrm{TM}}$ Plus (Thermo) coupled online to the UPLC. The electrospray voltage applied was $2.0 \mathrm{kV}$. The $\mathrm{m} / \mathrm{z}$ scan range was 350 to 1800 for full scan, and intact peptides were detected in the Orbitrap at a resolution of 70,000. Peptides were then selected for MS/MS using NCE setting as 28 and the fragments were detected in the Orbitrap at a resolution of 17,500. A data-dependent procedure that alternated between one MS scan followed by $20 \mathrm{MS} / \mathrm{MS}$ scans with 15.0s dynamic exclusion. Automatic gain control (AGC) was set at 5E4. Fixed first mass was set as $100 \mathrm{~m} / \mathrm{z}$.

\section{Bioinformatics Methods}

Gene Ontology (GO) annotation proteome was derived from the UniProt-GOA database (www. http://www.ebi.ac.uk/GOA/). Then proteins were classified by Gene Ontology annotation based on three 
categories: biological process, cellular component and molecular function. There, we used wolfpsort a subcellular localization predication soft to predict subcellular localization. Kyoto Encyclopedia of Genes and Genomes (KEGG) database was used to annotate protein pathway. Cluster analysis was used to study the differences and associations of specific proteins in specific functions such as KEGG pathway, protein domain and GO.

We first collated all the categories obtained after enrichment along with their $\mathrm{P}$ values, and then filtered for those categories which were at least enriched in one of the clusters with $P$ value $<0.05$. This filtered $P$ value matrix was transformed by the function $\mathrm{x}=-\log 10$ ( $P$ value). Finally these $\mathrm{x}$ values were $\mathrm{z}$-transformed for each functional category. These $z$ scores were then clustered by one-way hierarchical clustering (Euclidean distance, average linkage clustering) in Genesis. Cluster membership were visualized by a heat map using the "heatmap.2" function from the "gplots" R-package.Only interactions between the proteins belonging to the searched data set were selected, thereby excluding external candidates. STRING defines a metric called "confidence score" to define interaction confidence; we fetched all interactions that had a confidence score $>0.7$ (high confidence). Interaction network form STRING was visualized in R package "networkD3".

\section{Declarations}

\section{Competing interests}

The authors declare that they have no competing interests.

\section{Authors'contributions}

AFLconceived and designed the experiments. FXM, RH,HSL,JJL,XYC,JMS,CL and DGC performed the experiments. FXM, RH,FJL,SNZ,YZ,XLW and ZDZ analysed the data. FXM and AFLwrote the manuscript. All authors read and approved the final manuscript.

\section{Acknowledgements}

This work was financially supported by Agricultural Variety Improvement Project of Shandong Province(2019LZGC001) China Agriculture Research System(CaRS-3-1).

\section{References}

[1] Sun H Y,Yang J,Li YY. Research Progress on the Shape and Improvement of Wheat Nutritional Quality[J]. Modern Agricultural Technology, 2015, (16).

[2] Pu YY,Li NN,et al. Analysis of Chinese Wheat Protein Quality Characters and Research of progress of Main Influencing Factors[J]. Chinese Agricultural Science Bulletin, 2015, (15).

[3] Delcour J A, Joye I J, Lagrain B, et al. Wheat gluten functionality as a quality determinant in cereal-based food products. Annu Rev Food Sci Technol, 2012, 3: 469-492. 
[4] Rasheed A, Xia X C, He Z H, et al. Wheat seed storage proteins: advances in molecular genet ics, diversity and breeding applications. J Cereal Sci, 2015, 60:11-24.

[5] Wrigley CW, Asenstorfer R, Cornish GB, et al. The biochemical and molecular basis of wheat quality. In: Carver BF (ed) Wheat science and trade. Wiley-Blackwell, Ames, 2009, 495-520.

[6] Ribeiro M, Nunes-Miranda JD, Bran lard G, et al. One hundred years of grain omics:identifying the glutens that feed the world. J Proteome Res, 2013, 12:4702-4716.

[7] Altenbach SB. Proteomics of wheat flour. In: Colgrave ML(ed) Proteomics in food science.Academic Press, London, 2017, pp57-73.

[8] Liu L, Ikeda TM, Lerner SE et al. Comparison of low molecular weight glutenin subunits identified by SDSPAGE, 2-DE, MALDI-TOF-MS and PCR in common wheat. BMC Plant Biol, 2010,10:124.

[9] Mamone G, De Caro S, Ferranti P, et al. Proteomic-based analytical approach for the charaterization of glutenin subunits in durum wheat. J Mass Spectrom, 2009, 44: 1709-1723.

[10] Bromilow SN, Gethings LA, Bromley MJ, et al.Comprehen sive proteomic profiling of wheat gluten using a combination of data-independent and data-dependent acquisition. Front Plant Sci,20 7, 7:2020.

[11] Fiedler KL, McGrath SC, Callahan JH, et al. Characterization of grain-specific peptide markers for the detection of gluten by mass spectrometry. J Agric Food Chem ,2014,62:5835-5844.

[12] Schalk K,Lexhaller B, Koehler P, Scherf KA .Isolation and characterization of gluten protein types from wheat, rye, barley and oats for use as reference materials. PLoS ONE,2017, 12: e01728 19.

[13] Dupont FM, Vensel WH, Altenbach S B, et al. Deciphering the complexities of the wheat flour proteome using quantitative two-dimensional electrophoresis, three proteases and tandemmass spectrometry. Proteomic Sci, 2011, 9:10.

[14] Cho K, Beom H R, Simon-Buss A, et al.Proteomic profiling and epitope analysis of the complex $a$-, $Y$-and $\omega$-gliadin families in a commercial bread wheat.Front Plant Sci, 2018, 9: 8-18.

[15] Dong L L, Zhang XF, Zhang ZJ et al. New insights into the organization, recombination, expression and functional mechanism of low molecular weight glutenin subunitgenes in bread wheat. PLoSONE,2010, 5: e13548.

[16] Hurkman WJ, Tanaka CK, Altenbach SB, et al. Comparative proteomic analysis of the effect of temperature and fertilizer on gliadin and glutenin accumulation in the developing endosperm and flour from Triticum aestivum L. cv. Butte 86. Proteome Sci, 2013, 11:8.

[17] Zhang Y, Hu X, Islam S, et al. New insights into the evolution of wheat avenin-like proteins in wild emmer wheat (Triticum dicoccoides). Proc Natl Acad Sci USA, 2018,115:13312-13317. 
[18] Zhang YF, Lou H, Hou Z, et al. Identifying changes in the wheat kernel proteome under heat stress using iTRAQ. Crop J, 2018, 6: 600-610.

[19] Zhou J, Liu D, Yan Y, et al. Effects of water deficit on breadmaking quality and storage protein compositions in bread wheat (Triticum aestivum L.). J Sci Food Agric, 2018, 98:4357-4368.

[20]MaoFX.Formation and proteomics analysis of storage protein in winter wheat varieties with strong gluten [D]. Qingdao Agricultural University, 2019.

[21] He Z H, Liu L, Peña R J, et al. Composition of HMW and LMW glutenin subunits and their effects on dough properties, pan bread, and noodle quality of Chinese bread wheats. Cereal Chemistry, 2005, 82: 345350 .

\section{Figures}
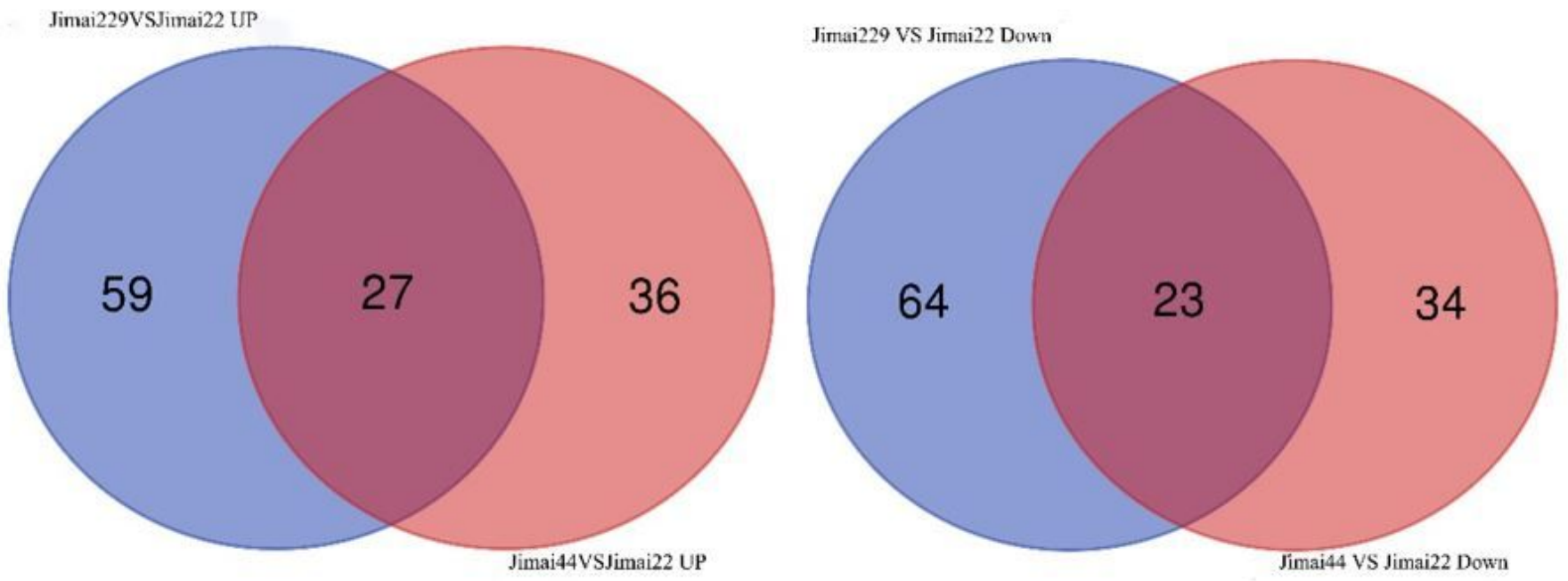

\section{Figure 1}

The Venn diagram of the differential protein of Jimai 44 Jimai 229 and Jimai 22
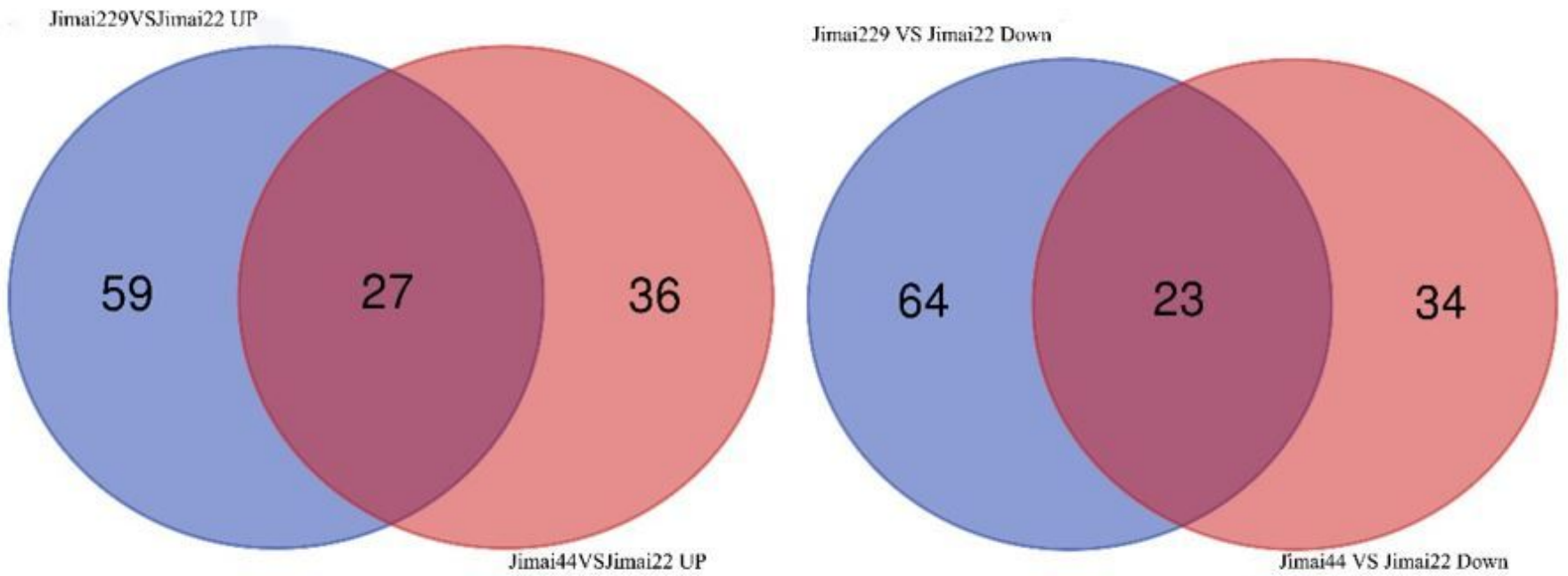


\section{Figure 1}

The Venn diagram of the differential protein of Jimai 44 Jimai 229 and Jimai 22

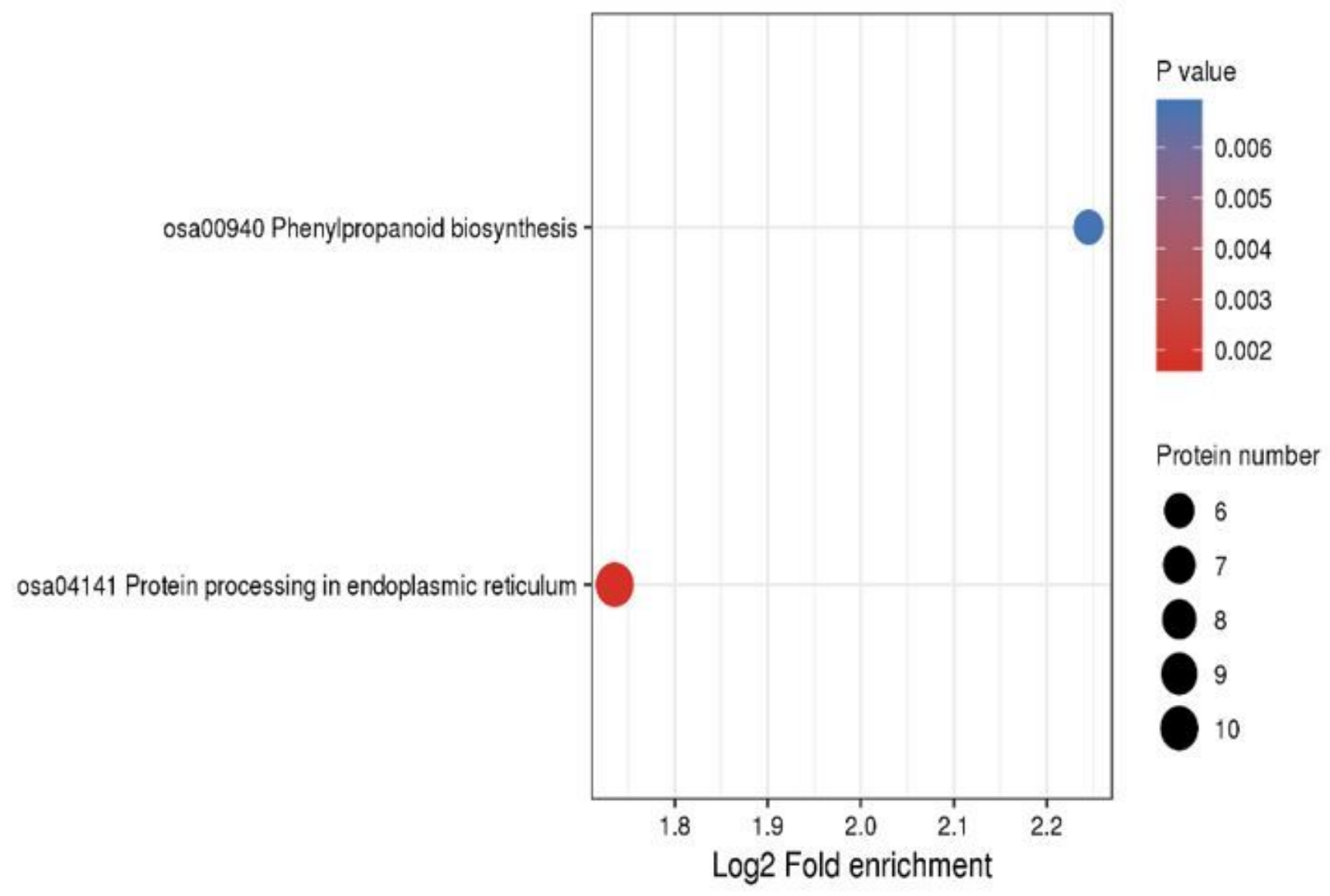

\section{Figure 2}

Bubble map of enrichment of differentially expressed proteins of Jimai 44 and Jimai 22 in KEGG pathway 


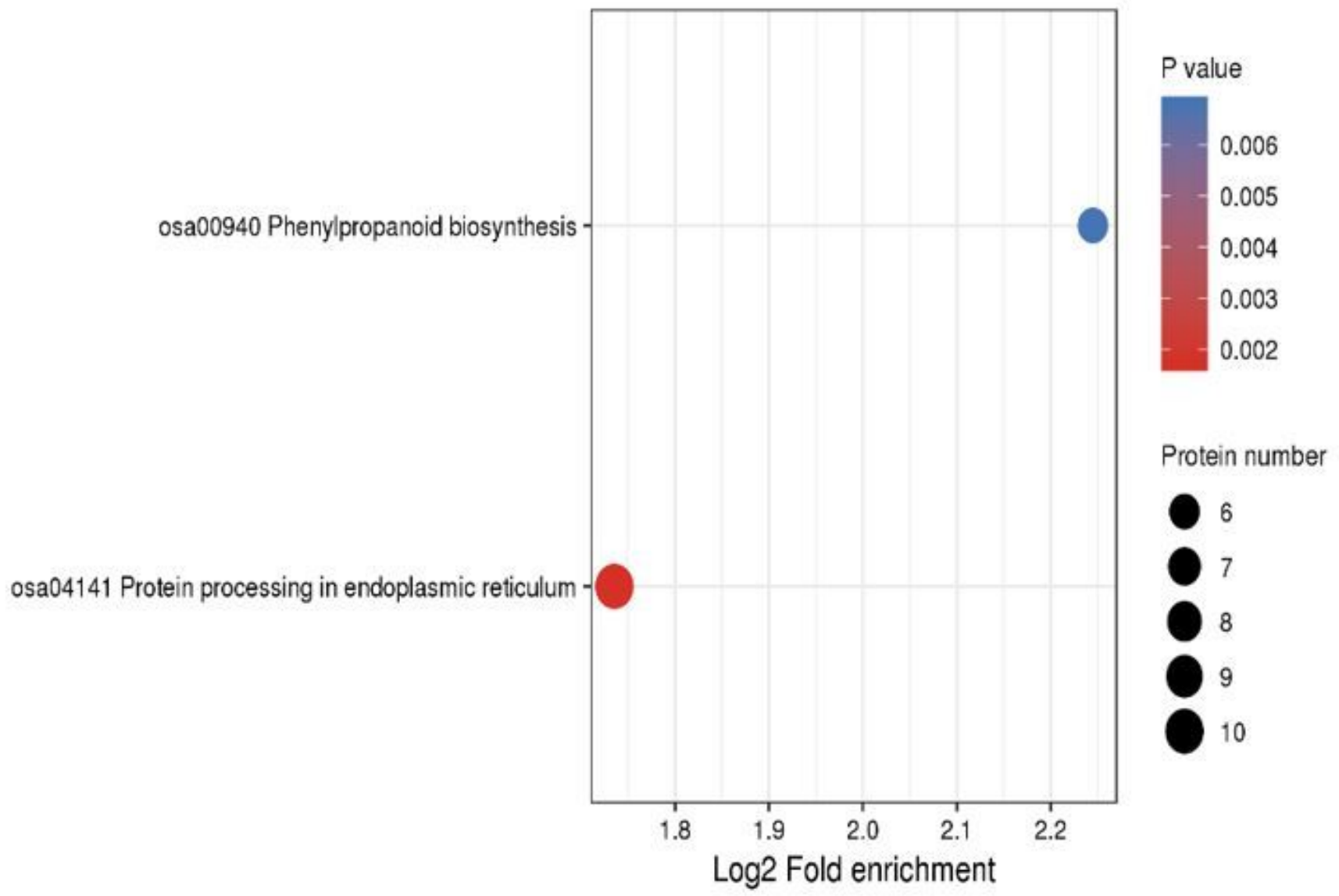

Figure 2

Bubble map of enrichment of differentially expressed proteins of Jimai 44 and Jimai 22 in KEGG pathway 


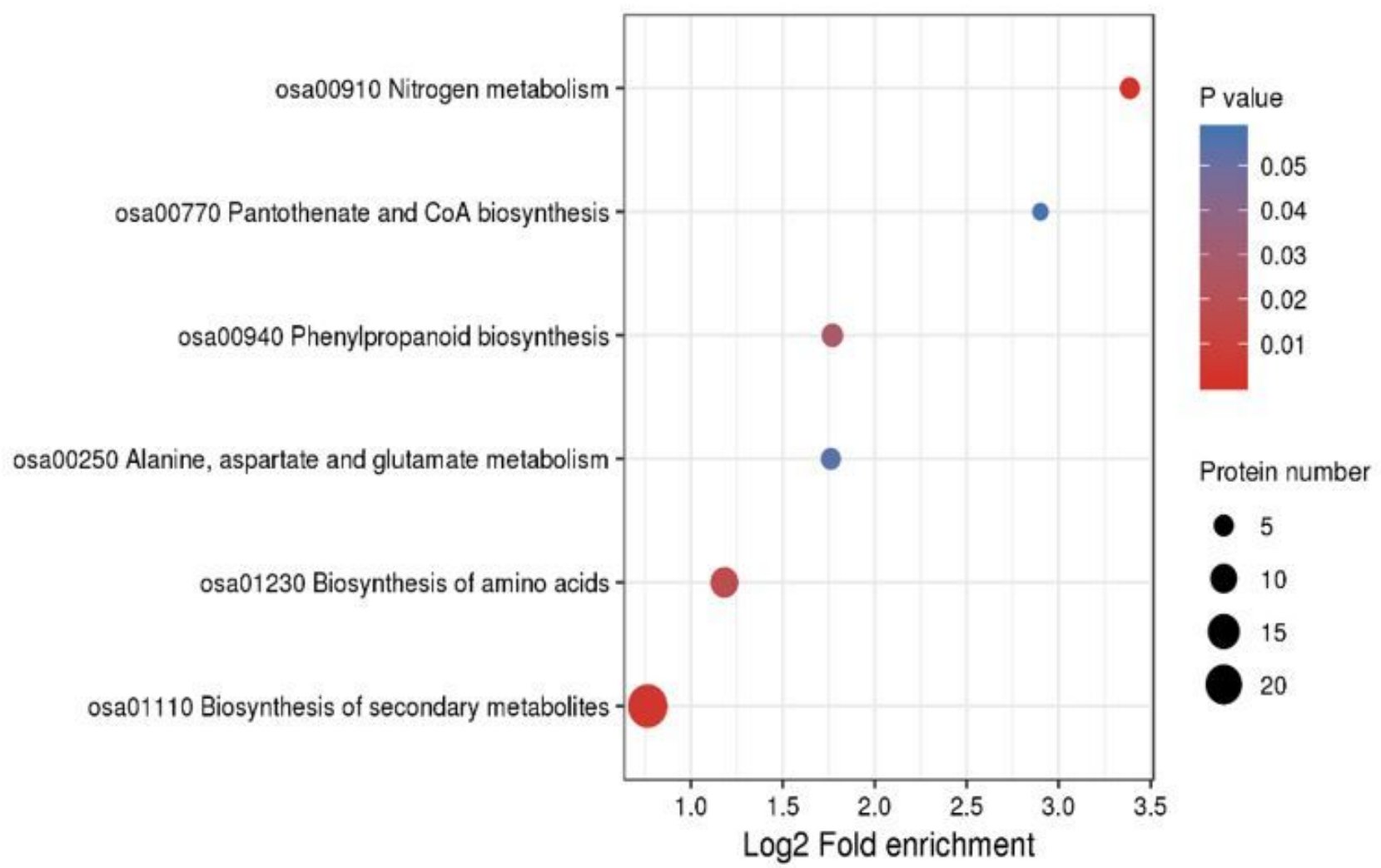

\section{Figure 3}

Bubble map of enrichment of differentially expressed proteins of Jimai 229 and Jimai 22 in KEGG pathway 


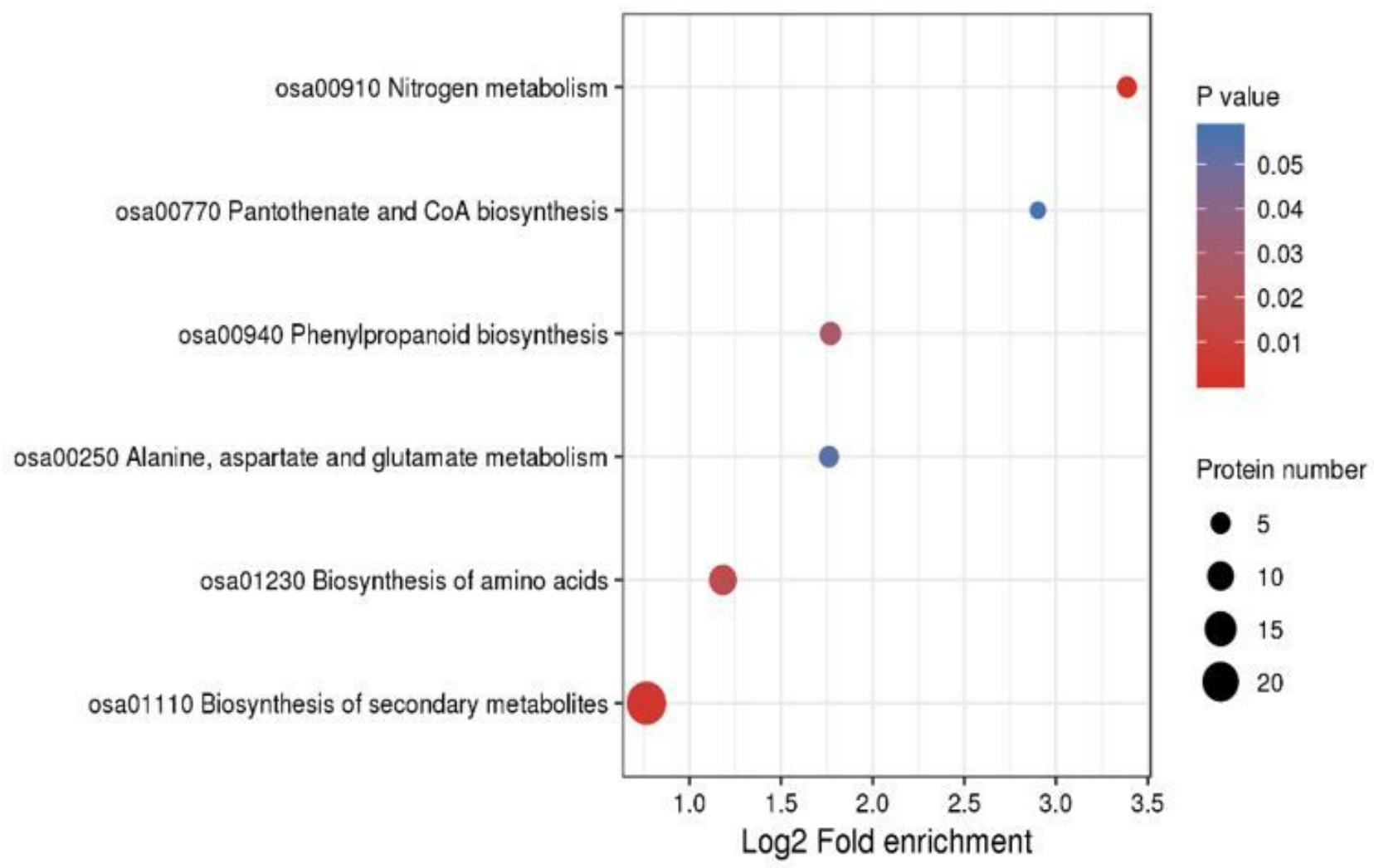

\section{Figure 3}

Bubble map of enrichment of differentially expressed proteins of Jimai 229 and Jimai 22 in KEGG pathway

A

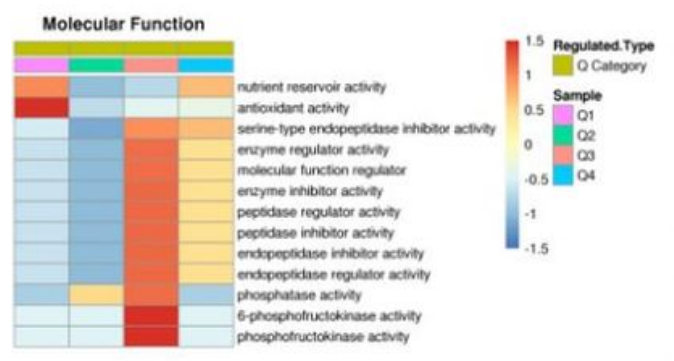

B

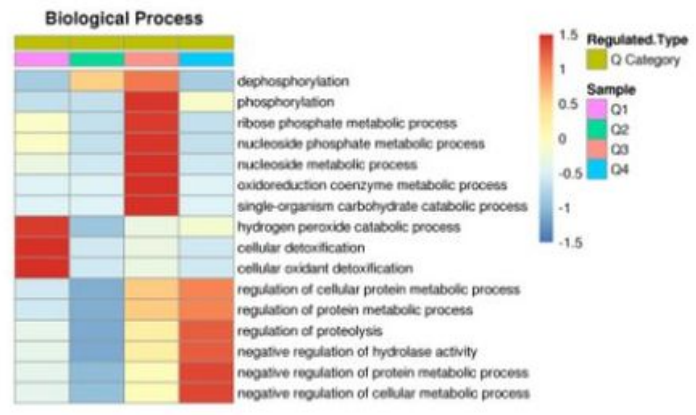

$\mathrm{C}$

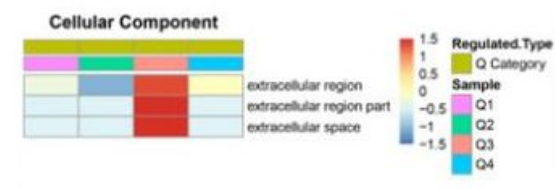

\section{Figure 4}

GO enrichment-based clustering analysis of the quantified proteins of jimai44 and jimai22 (A) Molecular function analysis; (B) biological process analysis; (C) cellular component analysis 
A

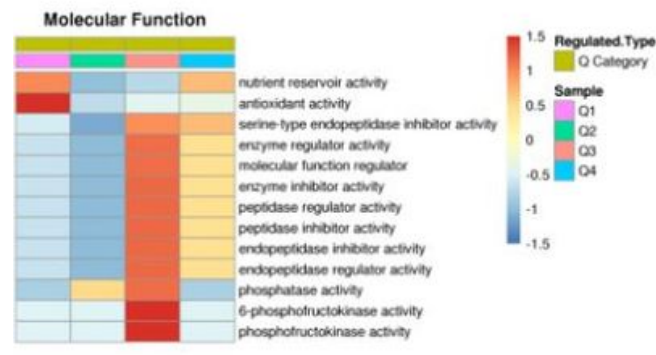

B

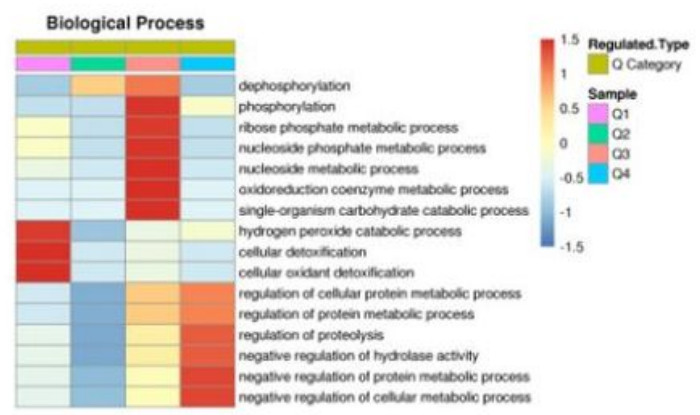

$\mathrm{C}$

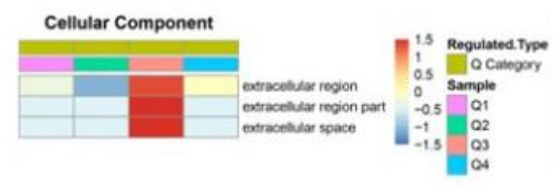

\section{Figure 4}

GO enrichment-based clustering analysis of the quantified proteins of jimai44 and jimai22 (A) Molecular function analysis; (B) biological process analysis; (C) cellular component analysis
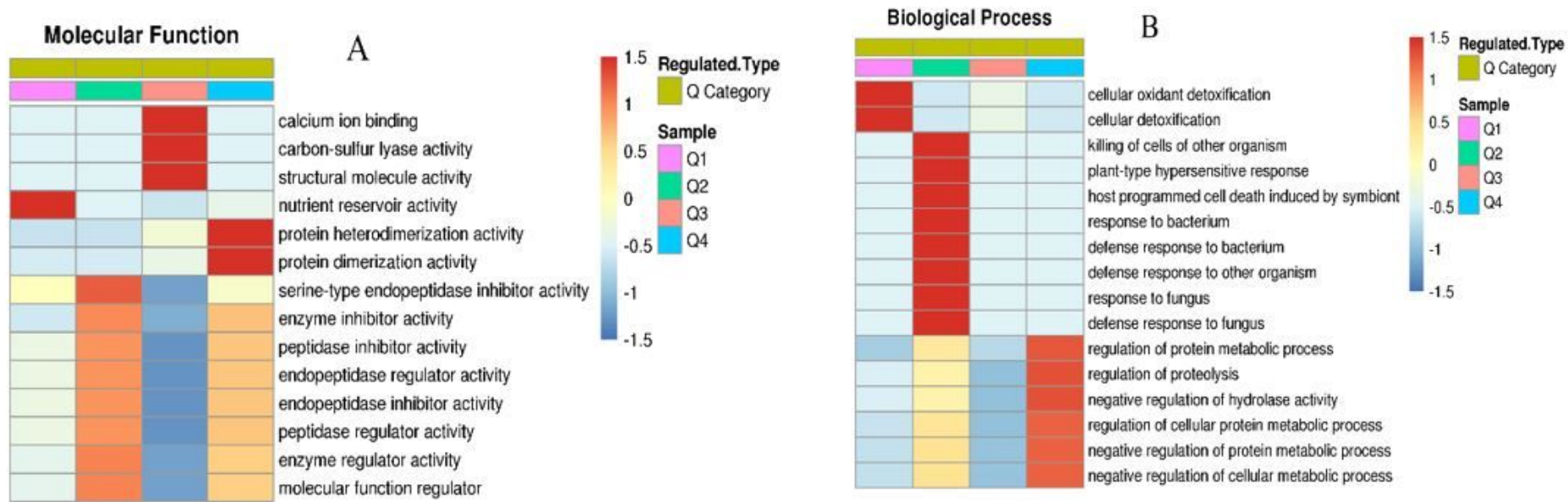

\section{Cellular Component}

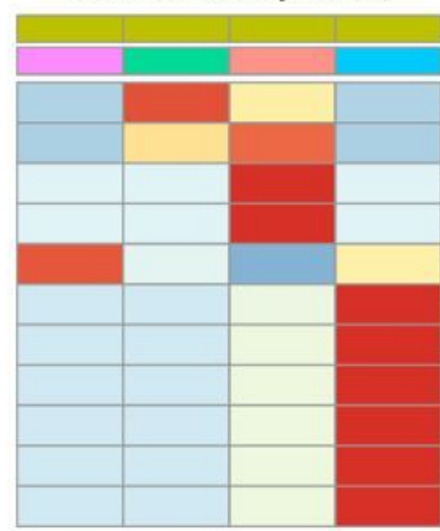

$\mathrm{C}$

endoplasmic reticulum endomembrane system cytoplasmic part macromolecular complex extracellular region chromosome nucleosome DNA packaging complex protein-DNA complex

chromatin

chromosomal part

\section{Figure 5}

GO enrichment-based clustering analysis of the quantified proteins of jimai229 and jimai22 (A) Molecular function analysis; (B) biological process analysis; (C) cellular component analysis 

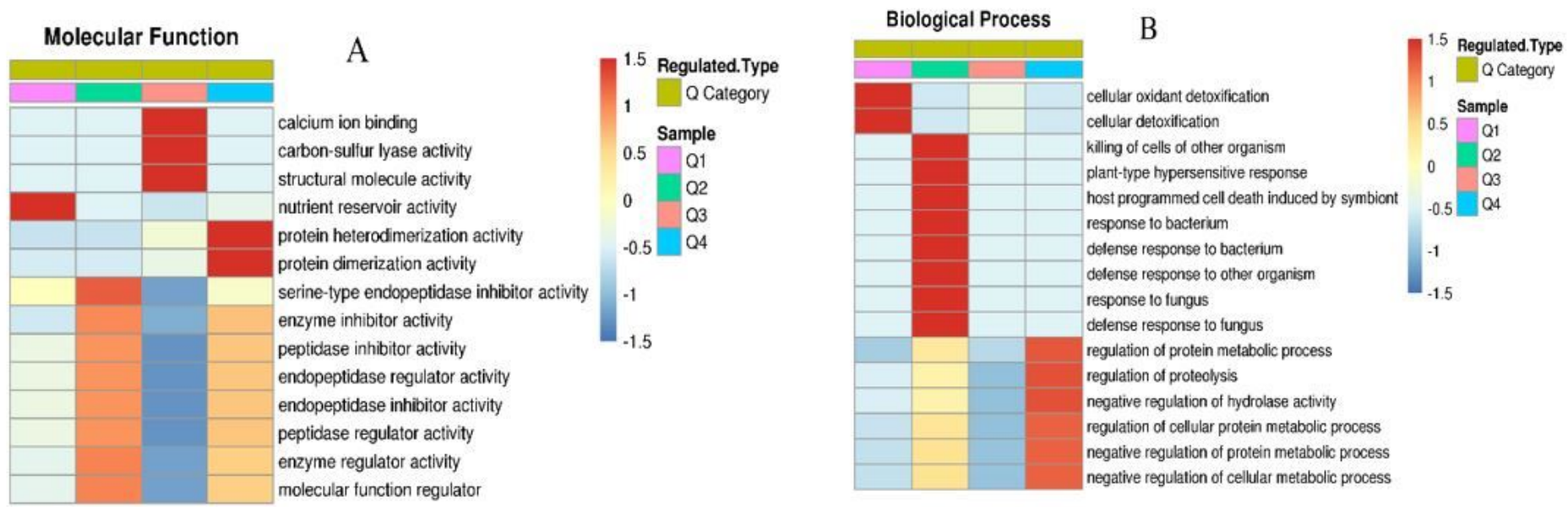

\section{Cellular Component}

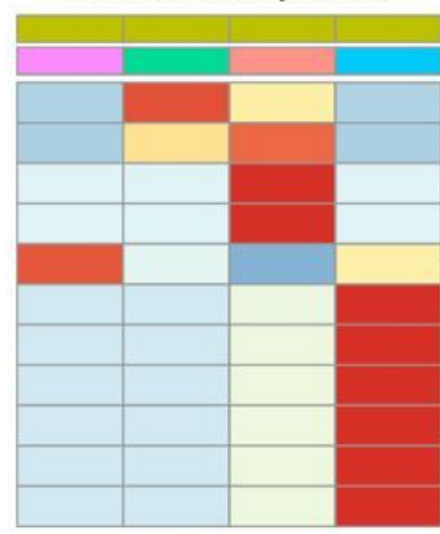

C

endoplasmic reticulum

endomembrane system

cytoplasmic part

macromolecular complex

extracellular region

chromosome

nucleosome

DNA packaging complex

protein-DNA complex

chromatin

chromosomal part

\section{Figure 5}

GO enrichment-based clustering analysis of the quantified proteins of jimai229 and jimai22 (A) Molecular function analysis; (B) biological process analysis; (C) cellular component analysis

A

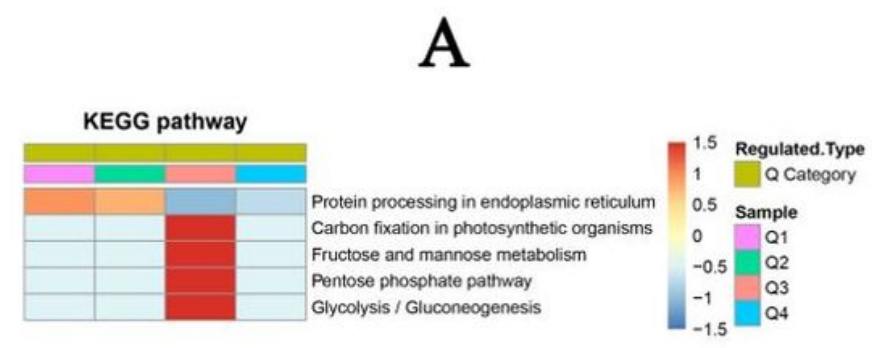

1.5 Regulated.Type

1 Q Category

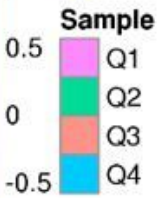

$-1$

$-1.5$

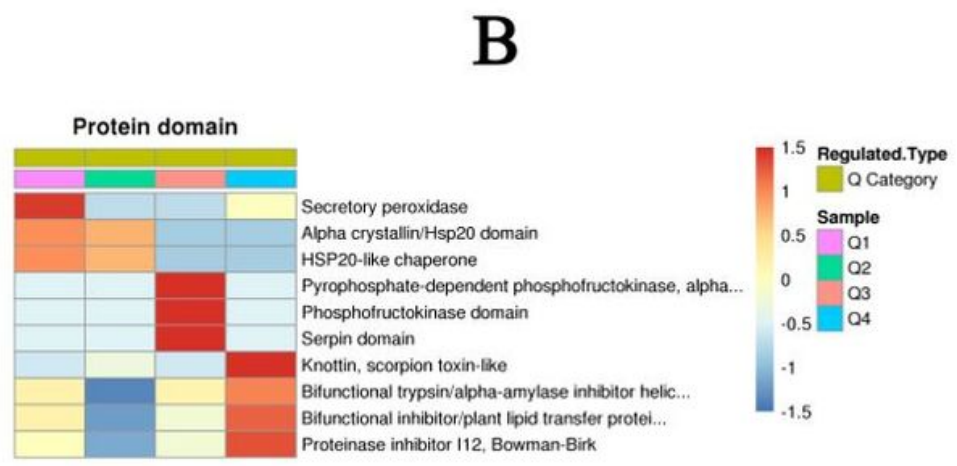

Figure 6

Functional enrichment-based clustering analysis of the quantified proteins of jimai44 and jimai22 (A)KEGG pathway; (B) protein domain 

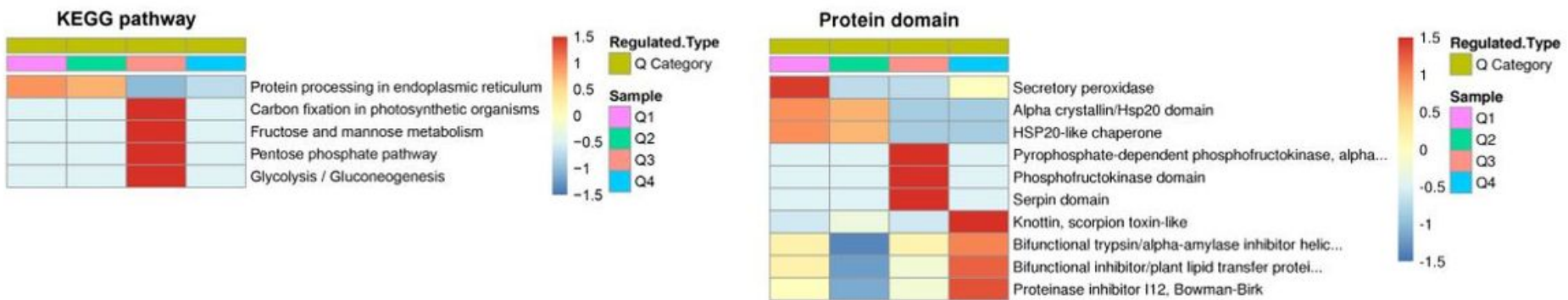

\section{Figure 6}

Functional enrichment-based clustering analysis of the quantified proteins of jimai44 and jimai22 (A)KEGG pathway; (B) protein domain

\section{KEGG pathway}

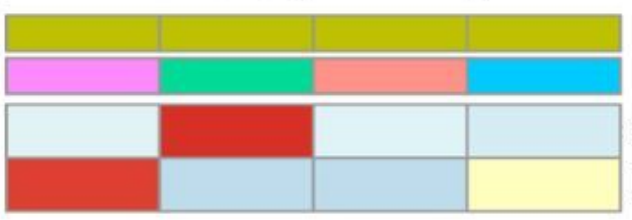

Protein processing in endoplasmic reticulum Nitrogen metabolism

A

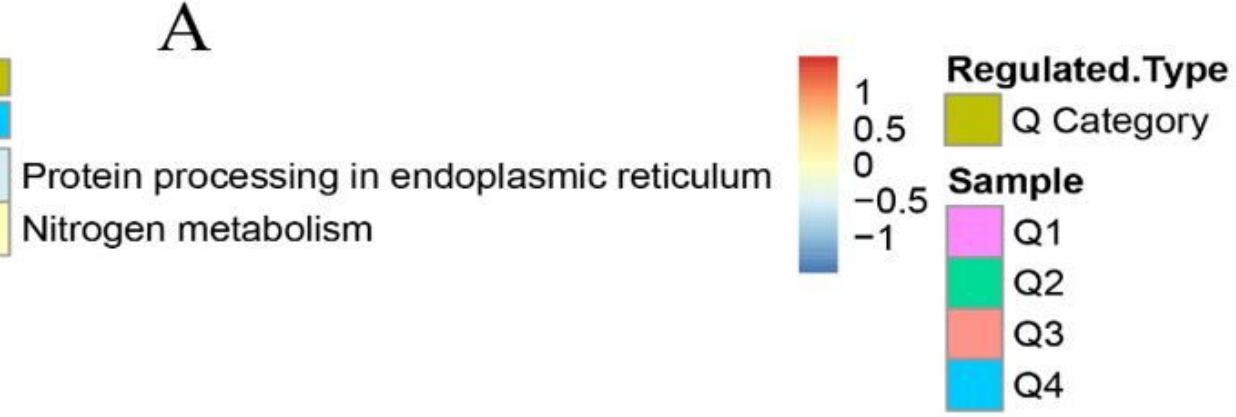

B

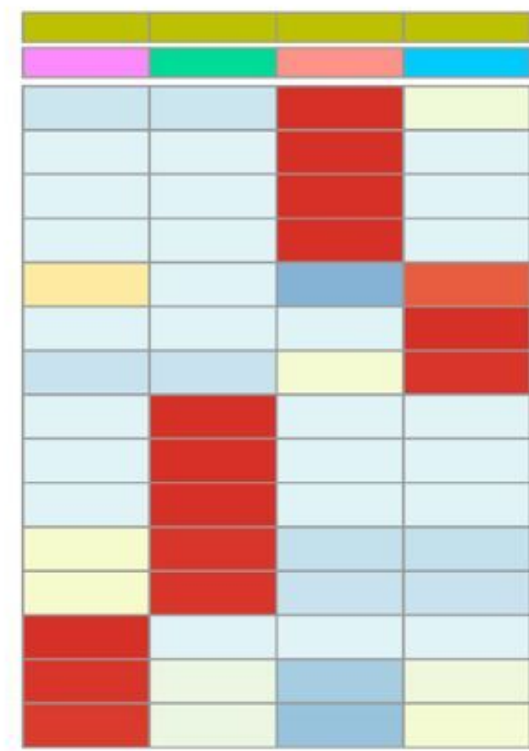

Armadillo-type fold

Calreticulin/calnexin, $\mathrm{P}$ domain

Concanavalin A-like lectin/glucanase domain

Coatomer, gamma subunit, appendage, Ig-like subdom...

Proteinase inhibitor 112, Bowman-Birk

Histone $\mathrm{H} 2 \mathrm{~A} / \mathrm{H} 2 \mathrm{~B} / \mathrm{H} 3$

Histone-fold

RlpA-like protein, double-psi beta-barrel domain

Barwin domain

1.5 Regulated.Type

1 Q Category

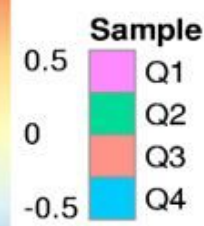

$-1$

$-1.5$

Heat shock chaperonin-binding

Alpha crystallin/Hsp20 domain

HSP20-like chaperone

Cupin 1

Bifunctional inhibitor/plant lipid transfer protei...

Bifunctional trypsin/alpha-amylase inhibitor helic...

\section{Figure 7}

Functional enrichment-based clustering analysis of the quantified proteins of jimai229 and jimai22(A) KEGG pathway; (B) protein domain 


\section{KEGG pathway}

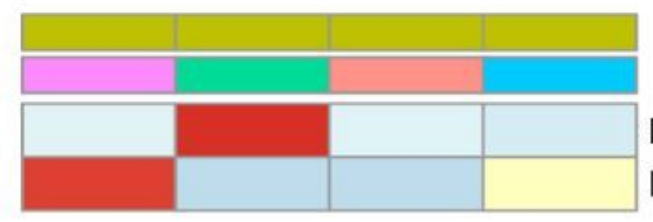

Protein processing in endoplasmic reticulum Nitrogen metabolism

A

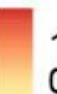

1 Regulated.Type

$0.5 \quad Q$ Category

-0.5 Sample

$-1 \quad$ Q1

Q2

Q3

Q4

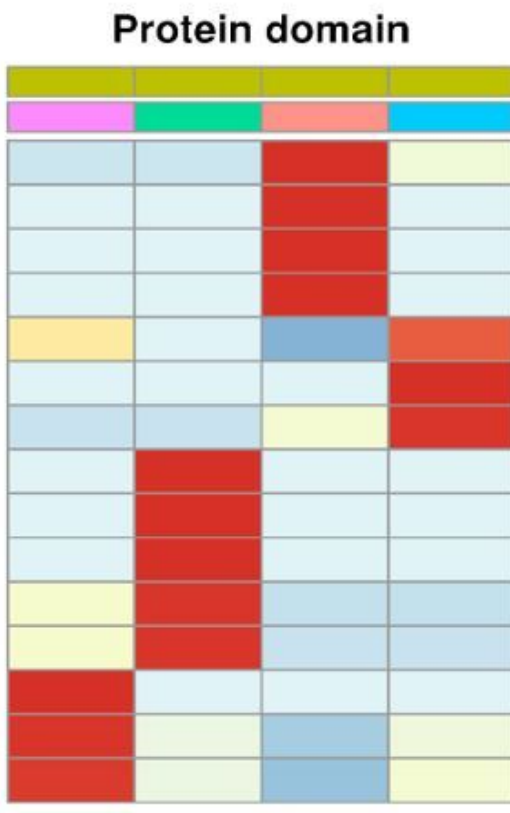

B

Armadillo-type fold

Calreticulin/calnexin, $\mathrm{P}$ domain

Concanavalin A-like lectin/glucanase domain

Coatomer, gamma subunit, appendage, Ig-like subdom...

Proteinase inhibitor 112, Bowman-Birk

Histone $\mathrm{H} 2 \mathrm{~A} / \mathrm{H} 2 \mathrm{~B} / \mathrm{H} 3$

Histone-fold

RlpA-like protein, double-psi beta-barrel domain

Barwin domain

Heat shock chaperonin-binding

Alpha crystallin/Hsp20 domain

HSP20-like chaperone

Cupin 1

Bifunctional inhibitor/plant lipid transfer protei...

Bifunctional trypsin/alpha-amylase inhibitor helic...

\section{Figure 7}

Functional enrichment-based clustering analysis of the quantified proteins of jimai229 and jimai22(A) KEGG pathway; (B) protein domain 